\title{
SENSORY PROFILE OF BRAZILIAN COFFEES BASED ON CONSUMER PERCEPTION AS AN ALTERNATIVE TO THE CONVENTIONAL METHODS
}

\author{
Marcela de Alcantara ${ }^{1}$, Daniela De Grandi Castro Freitas-Sá2
}

(Received: October 04, 2017; accepted: December 11, 2017)

\begin{abstract}
Consumer-based methodologies for sensory characterization of foods have been widely discussed and are satisfactory, when compared to the results of trained panelists. However their efficiency in the description of complex foods rich in sensory attributes (flavor and aroma) such as coffee still needs to be explored. Polarized sensory positioning (PSP) is an innovative methodology for sensory characterization, based on the comparison of samples with reference products. In this study, roasted and ground coffees with different quality ratings according to the Coffee Quality Program (PQC) of the Brazilian Coffee Industry Association (ABIC) - Traditional, Superior and Gourmet - were evaluated by this method, applied to consumers. The beverage was presented to 100 consumers, who quantified the degree of global difference between the samples and the chosen references, using unstructured scales, followed by the verbal description of the sensory characteristics perceived in each sample evaluated. The samples were described for 30 attributes related to visual appearance, aroma, flavor, texture and hedonic terms. The method presented a good discriminative capacity, since it was able to differentiate the samples according to the PQC classification. In addition it allowed to identify the main sensory characteristics responsible for similarities and differences between the samples. The results indicate that consumers were able to infer about a quality classification based on their own perception and vocabulary, and the Brazilian traditional coffee was considered inferior to specialty coffees increasingly available in the market.
\end{abstract}

Index Terms: Sensory description, polarized sensory positioning, coffee quality, consumer science.

\section{PERFIL SENSORIAL DE CAFÉS BRASILEIROS ATRAVÉS DA PERCEPÇÃO DO CONSUMIDOR COMO ALTERNATIVA AOS MÉTODOS CONVENCIONAIS}

\begin{abstract}
RESUMO: Metodologias baseadas na percepção do consumidor para obter a caracterização sensorial de alimentos vêm sendo amplamente discutidas apresentando-se satisfatórias quando comparadas aos resultados de avaliadores treinados. Porém, a eficiência delas na caracterização de alimentos complexos e ricos em atributos sensoriais de sabor e aroma, como o café, ainda deve ser explorada. O posicionamento sensorial polarizado (PSP) é uma metodologia inovadora para a caracterização sensorial que se baseia na comparação entre amostras e um conjunto de produtos de referência. Neste estudo, cafés torrado e moído com diferentes classificações segundo o Programa de Qualidade do Café (PQC) da Associação Brasileira da Indústria do Café (ABIC) - Tradicional, Superior e Gourmet - foram avaliados utilizando esta metodologia aplicada com consumidores. As bebidas foram avaliadas por 100 consumidores que quantificaram o grau de diferença global entre as amostras e as referências escolhidas utilizando escalas não estruturadas, seguido da descrição verbal das características sensoriais percebidas em cada amostra avaliada. As amostras foram descritas por 30 atributos relacionados à aparência visual, ao aroma, ao sabor, à textura e a termos hedônicos. O método apresentou uma boa capacidade discriminativa, tendo em vista que conseguiu segmentar as amostras de acordo com a classificação do PQC. Além disso, permitiu identificar as principais características sensoriais responsáveis pelas semelhanças e diferenças entre as amostras. Os resultados indicaram que os consumidores foram capazes de inferir sobre uma classificação de qualidade segundo sua percepção e linguagem, sendo o café tradicional brasileiro considerado inferior aos cafés especiais, que estão cada vez mais acessíveis no mercado.
\end{abstract}

Termos para indexação: Descrição sensorial, posicionamento sensorial polarizado, qualidade de café, estudo de consumidor.

\section{INTRODUCTION}

Information on the sensory characteristics of food and beverage is essential for successful product development and marketing. Those informations are obtained mainly by trained panelists through descriptive sensory methods and consumers are asked about preference and acceptance, not providing information on how they perceive the sensory characteristics of products. In addition to that, most existing descriptive techniques require the maintenance of trained panelists and the use of unstructured scales to evaluate products. It makes analyses timeconsuming and costly due to exhaustive training sessions, so that the problems with the use of scales are minimized (LAWLESS; HEYMANN, 2010).

In order to reduce the analysis time and costs inherent to conventional descriptive tests, recent research has sought to develop methodologies that can be applied to consumers and allow the rapid description of foods, making it possible

${ }^{1}$ Universidade Federal Rural do Rio de Janeiro - Instituto de Tecnologia - Rodovia BR 465, Km 07, s/n - Zona Rural - 23.890-000 Seropédica - RJ - marceladealcantara@gmail.com

${ }^{2}$ Embrapa Agroindústria de Alimentos - Av. das Américas 29501 - Guaratiba - 23.020-470 - Rio de Janeiro - RJ daniela.freitas@embrapa.br 
for the industry to use them. These innovative methodologies have rapidly gained popularity and become one of the most active and dynamic areas of sensory science research in recent years. Besides being quicker and easier to understand by participants, when using consumers for product descriptions, these techniques are also intended to bring products to the market that actually have the characteristics expected by the target audience, and are useful for providing valuable information during the development of new products or in the design of marketing campaigns (ARES et al., 2010; ARES et al., 2011; DOOLEY et al., 2010; JAEGER et al., 2015; LAAKSONEN et al., 2016; REINBACH et al., 2014; ROUSSEAU, 2015; VEINAND et al., 2011). Besides providing sensory configurations similar to those obtained by conventional descriptive analysis, the methods presented have shown efficiency in sample differentiation, even using consumers in the evaluation (ARES et al., 2014; BRUZZONE et al., 2012; CADENA et al., 2014; FLEMING et al., 2015; JAEGER et al., 2013; LADO et al., 2010; REINBACH et al., 2014; VARELA; ARES, 2012; VARELA et al.; 2014).

Coffee is one of the most consumed beverages worldwide. The association between coffee consumption and a variety of conditions and diseases has been examined extensively. Besides its economic importance, coffee consumption has been currently encouraged by health experts, since research indicates that coffee is a reducing agent for the risk of some types of cancer, due to antioxidant and anticarcinogenic substances naturally present in coffee, or those formed during its processing (ARRUDA et al., 2009). Grosso et al. (2017) evaluated the associations between coffee and caffeine consumption and various health outcomes in an umbrella review of the evidences from meta-analyses of observational studies and randomized controlled trials (RCTs). This study showed that there is probable evidence of the beneficial effects of coffee consumption for a number of chronic diseases, including some cancers (endometrial, prostate, colorectal, and liver), cardiovascular disease and metabolicrelated outcomes (such as type-2 diabetes and metabolic syndrome), and neurological conditions (such as Parkinson's disease, Alzheimer's disease, and depression).

Although the use of some methodologies based on consumer perception such as sorting, check-all-that-pply, projective mapping and polarized sensory positioning is already established as a way to obtain reliable sensory characteristics more quickly than with a trained panelists, little is known about their efficiency in the characterization of complex foods, rich in sensory attributes (flavor and aroma), such as coffee, wines, chocolate, spirits and beers. Physical aspect and cup-tasting are the main procedures to evaluate coffee quality commercially. In the literature, the most used sensory tools for this beverage description in recent years are: cuptasting by a small number of experts (two or three) certified by the Specialty Coffee American Association - SCAA (ALVES et al., 2017; ISQUIERDO et al., 2012; Lópes-Gracía et al., 2016;SILVA et al., 2014), Brazil Specialty Coffee Association - BSCA (SILVEIRA et al., 2016) and in accordance to Resolution SAA-37 (PINO et al., 2017); and quantitative descriptive analysis with trained panelists (DELLA MODESTA et al., 1999; MONTEIRO, 2002; MONTEIRO et al., 2005; SANTOS et al., 2013; SILVA, 2003). On the other hand, few consumer studies have been using hedonic scale and multivariate data analysis, reporting on acceptability, emotions, perceptions and consumer behavior in different consumption contexts (FRANCISCO; et al., 2014; OLIVEIRA, 2008; OSSANI et al., 2017).

In Brazil, the Coffee Quality Program (PQC) launched in 2004 by the Brazilian Coffee Industry Association (ABIC) certifies the quality of the final beverage obtained through roasted and ground coffee, using a sensory analysis methodology validated by the ABIC, which classifies and differentiates coffees into categories. The evaluation of coffee quality is performed by trained panelists in accredited laboratories and takes into account aroma of ground coffee, aroma, acidity, body, astringency and bitterness, among other beverage characteristics. The coffee quality category is determined according to the Global Quality score, obtained by the product on a scale of 0 to 10 . The minimum score of a recommended beverage corresponds to 4.5 points and, according to the received score, coffee is classified as Extra Strong, Traditional, Superior or Gourmet (ABIC, 2017). Specialty coffees are evaluated and certified by the BSCA. They are certified in batches and analyzed by three panelists of the association. Roasted and ground beans are evaluated for the aspects: clean drink, sweetness, acidity, body, taste, residual taste and overall balance. To be certified, the coffee must score greater than or equal to 80 and no parameter can be equal to zero (BSCA, 2017). 
Polarized sensory positioning (PSP) is a new methodology based on consumer perception that consists in comparing the samples with a set of fixed references, called poles (TEILLET, 2014). This methodology allows assessors to quantify the overall degree of difference between each sample and each of the chosen poles using scales, ranging from "exactly the same" to "totally different" (TEILLET et al., 2010). The usual number of poles used in studies with PSP is three and, in pole selection, the main sensory characteristics responsible for similarities and differences between samples should be considered (ANTÚNEZ et al., 2015; ARES et al., 2015; CADENA et al., 2014; DE SALDAMANDO et al, 2013; TEILLET, 2014).

In this study, the sensory description of roasted and ground coffee with different ratings according to the Coffee Quality Program (PQC) of the Brazilian Coffee Industry Association (ABIC) was obtained, using consumer perception through polarized sensory positioning (PSP).

\section{MATERIAL AND METHODS}

\section{Samples}

Seven samples of roasted and ground coffee - 3 classified as Traditional, 2 as Superior and 2 as Gourmet - were purchased from the local market in the city of Rio de Janeiro, selected from companies certified by the ABIC Coffee Quality Program (PQC). The traditional and superior coffees were selected from among the 14 largest associated coffee industries of the $\mathrm{ABIC}$, according to a report published in October 2014 (ABIC, 2014). The samples codes and characteristics of the coffees regarding the quality shown in the label, bean species, classification of the beverage and roasting are presented in Table 1. These characteristics were obtained from the packages.

Samples T3, S1 and G1 were chosen as poles (references). Poles were selected taking into account the main sensory characteristics responsible for differences among samples, based on results from preliminary study with trained panelists.

The samples were prepared in Britânia coffee machines (NCB27) with a large paper filter No. 4, using mineral water and coffee powder at a proportion $100 \mathrm{~g}$ of powder/L of mineral water, according to the preparation recommendation by the ABIC (2004). They were served in $40-\mathrm{mL}$ portions at $70^{\circ} \mathrm{C}$ in white porcelain cups kept in an oven at $70^{\circ} \mathrm{C}$ and coded with random threedigit numbers. Samples were evaluated in two distinct sessions of 4 and 3 samples, per consumer, at intervals of at least 4 hours. Consumers were instructed to sweeten or not samples according to their regular consumption way. Sucrose and sucralose were offered to sweeten bevareges according to the assessor's preference (SANTOS, 2010). Mineral water at room temperature was offered to the consumer to eliminate taste interference between tastings. The beverage was kept in the coffeemaker and considered appropriate for consumption within a maximum time of 30 minutes (FERIA-MORALES, 1989), after which they were discarded.

\section{Consumers}

A total of 100 consumers (68\% women; 18 65 years) participated in this study. Participants were recruited among Embrapa Agroindústria de Alimentos employees and trainees who showed interest in the study, time availability, affinity for the product and good health conditions. Study was approved to local research ethics committee (CAAE 54935116.9.0000.5284). The participants signed a Free and Informed Consent Term and received a small gift for their participation.

\section{Polarized Sensory Positioning}

Consumers received three poles and one sample, served in $40-\mathrm{mL}$ portions at $70^{\circ} \mathrm{C}$, in white porcelain cups kept in an oven at $70^{\circ} \mathrm{C}$. The poles, denominated as R1, R2 and R3, were presented simultaneously in this order from left to right. The samples were coded with random three-digit numbers and were presented in a balanced order (MACFIE et al., 1989).

Participants were asked to taste the poles and try to memorize their sensory characteristics. They were then invited to try each of the samples, monadically, and evaluate the overall difference between the sample and each pole using a 10$\mathrm{cm}$ unstructured scale anchored with the terms "exactly the same" to the left and "totally different" to the right. Consumers were informed that they had to perform the task according to their own criteria, and that there were no right or wrong answers. In addition, they were advised to try the poles as many times as they thought necessary. After comparing each sample with the poles, consumers were asked to write up to three words capable of describing the sensory characteristics of the sample in question. 
TABLE 1 - Characteristics of the coffee samples used in the study

\begin{tabular}{ccccc}
\hline Samples & Classification PQC & Coffee specie & $\begin{array}{c}\text { Classification } \\
\text { Beverage* }\end{array}$ & Roast \\
\hline T1 & Traditional & Arabica & "Dura" & Medium \\
T2 & Traditional & ND & ND & ND \\
T3 & Traditional & ND & ND & ND \\
S1 & Superior & Arabica & "Dura" & Medium \\
S2 & Superior & ND & ND & ND \\
G1 & Gourmet & Arabica & Light & ND \\
\hline
\end{tabular}

ND - Not declared

*BRAZILIAN OFFICIAL COFFEE CLASSIFICATION - COB. CETCAF (2014)

This initial verbalization was preprocessed (grouping of synonyms, management of ambiguous words) to obtain the final descriptions used in data analysis.

The tests were performed at the Sensory Analysis Laboratory of Embrapa Agroindústria de Alimentos, in Rio de Janeiro, in individual booths, under white lighting. Data were collected using the Fizz software (Biosystemes, France).

\section{Data analysis}

Data were analyzed using Multiple Factor Analysis (MFA) in order to preserve individual data and to compensate individual differences when evaluating the similarities and differences between samples and poles (TEILLET, 2014). For each sample, the mean intensity scores was calculated, and a matrix containing samples in rows and poles in columns was constructed. MFA was performed, taking into account the data of each consumer as a separate group of variables. The descriptors provided by consumers were analyzed qualitatively and quantitatively. A qualitative analysis of the words elicited by consumers in the description step was performed. Those that were considered synonyms or inflections of the same word were merged into categories and their frequency of mention was determined by counting the number of consumers who used the terms within each category. Those terms mentioned by less than $10 \%$ of the consumers were excluded for further analysis (ARES et al., 2010). The frequency table, containing the frequency of terms of each category for the description of each of the samples, was constructed and considered as a group of supplementary variables in the
MFA. The confidence ellipses were calculated using truncated total bootstrapping considering the first four dimensions of the configurations (DEHLHOLM et al., 2012).

All statistical analyses were performed using the FactoMineR package of the $\mathrm{R}$ language software (R CORE TEAM, 2014).

\section{RESULTS AND DISCUSSION}

The sensory description of coffee was carried out in four 6-hour sessions, totaling 24 hours for application and data collection.

Consumers characterized the samples through 30 attributes, 3 related to appearance, 7 to aroma, 14 to flavor, 3 to mouthfeel and 3 to hedonic attributes (Table 2). Each consumer generated an average number of 15 attributes (1 for visual appearance, 2 for aroma, 10 for flavor, 1 for body and 1 hedonic). These attributes were: dark, light, without oiliness, characteristic aroma, weak aroma, pleasant aroma, strong aroma, burnt aroma, sweet aroma, mild aroma, strong flavor, bitter taste, burnt flavor, weak flavor, mild flavor, characteristic flavor, sweet taste, cereal flavor, residual flavor, non-characteristic flavor, acid taste, metal flavor, bitter residual, tasteless, fullbodied, thin, astringent, pleasant, tasty, bad.

PSP enabled the identification of sensory characteristics of the beverages through consumer vocabulary. It was also observed that consumers used some hedonic terms (pleasant, tasty, bad - Table 2) in beverage description that are not obtained when descriptive analysis were performed with trained panelists. The description obtained by PSP using sensory and hedonic terms was also reported in other studies (ARES et al., 2011; VEINAND et al., 2011). 
TABLE 2 - Attributes used by consumers to describe coffee beverages.

\begin{tabular}{lcll}
\hline Attribute & Number of mentions Attribute & Number of mentions \\
\hline \multicolumn{1}{c}{ Appearance } & \multicolumn{2}{c}{ Aroma } \\
Dark & 55 & Characteristic & 32 \\
Light & 13 & Weak & 26 \\
Without oiliness & 10 & Pleasant & 25 \\
\multicolumn{1}{c}{ Flavor } & & Strong & 19 \\
Strong & 183 & Burnt & 13 \\
Bitter & 173 & Sweet & 12 \\
Burnt & 80 & Mild & 13 \\
Weak & 56 & & Mouthfeel \\
Mild & 45 & Full-bodied & 61 \\
Characteristic & 44 & Thin & 37 \\
Sweet & 31 & Astringent & 14 \\
Cereal & 22 & & Hedonic \\
Residual & 17 & Pleasant & 33 \\
Non-characteristic & 17 & Tasty & 20 \\
Acid & 16 & Bad & \\
Metal & 12 & & \\
Bitter Residual & 9 & & \\
Tasteless & 9 & & \\
& & &
\end{tabular}

Cadena et al (2014) considered the use of hedonic terms a limitation on the sensory characterizations obtained from the consumer, although this information can be used to identify sensory characteristics relevant to consumers in the design of marketing and communication strategies.

The sensory configuration of coffee samples is presented in the dimensional space obtained through MFA (Figure 1). The first two dimensions accounted for $50.43 \%$ of the variance in the experimental data. The evaluated beverages were clearly differentiated into three groups of samples similar to each other. Within each distint group, confidence ellipses of samples overlaped in the first and second dimensions, showing that were considered similar on their sensory characteristics. A group formed by the traditional beverages T1, $\mathrm{T} 2$ and T3 and by the gourmet beverage G2; a second group formed by the superior beverages $\mathrm{S} 1$ and S2; and a third group formed by the gourmet sample G1; they were therefore classified, according to the classification proposed by the ABIC, except sample G2. This fact indicates a good differentiation capacity of the PSP method in this study. Despite being classified with a gourmet label, sample G2 were positioned at sensory configuration together traditional beverages, possiblly because it had sensory characteristics similar to the traditional certified coffees selected for this study Moreover, this fact is linked with sensory dimension generated by the set of samples avaliated. De Saldamando et al. (2013) indicated that different sets of poles could affect conclusions regarding similarities and differences among products to some extent. It means that chosen poles could affect discrimination in specific dimensions so that some sensory dimensions could be more interesting than others (not necessarily the main sensory dimensions), as suggested by Ares et al. (2015). In other words, discriminative conformation obtained in the present study is dependent of the sensory dimension generated by the set of products avaliated: poles and samples.

The results are in agreement with those reported by Varela et al. (2014), who demonstrated the good differentiation capacity of this methodology. In fact, PSP has the additional advantages such as enabling the comparison of sample configurations from different sessions, which cannot easily be achieved using the other two rapid methodologies (ANTÚNEZ et al., 2015; ARES; VARELA, 2014; CADENA et al., 2014; VARELA; ARES, 2012). 

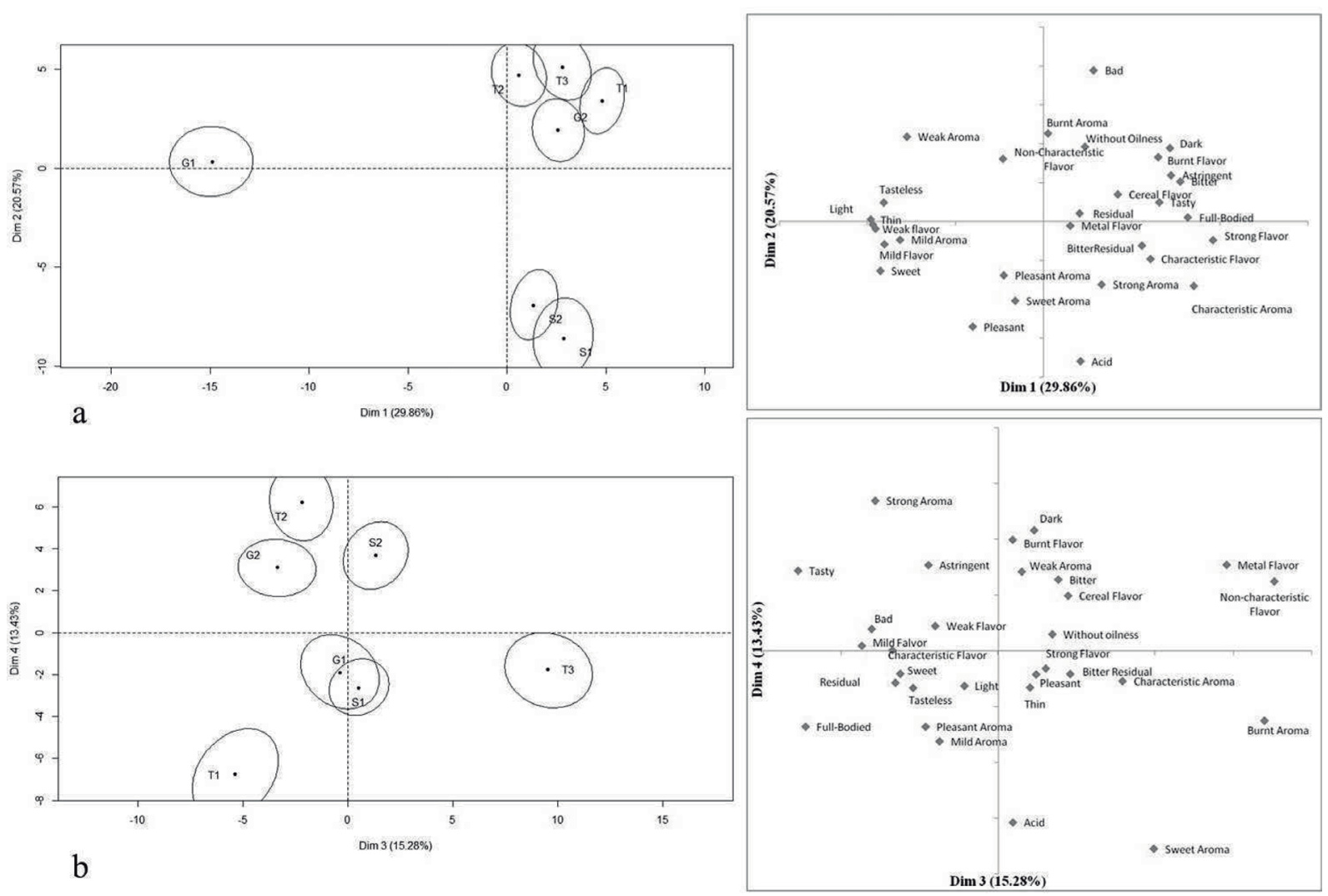

FIGURE 1 - Representation of samples and terms in the first and second dimensions of multiple factorial analysis (MFA) on polarized sensory positioning data. T1, T2 and T3 - Traditional; S1 and S2 - Superior; G1 and G2 Gourmet.

Antúnez et al. (2015) confirmed that data aggregation of data collected in different sessions with different assessors using PSP provides similar information to the evaluation of samples in a single session. This characteristic of PSP makes it a particularly interesting alternative when using consumer-based characterizations for new product development (ANTÚNEZ et al., 2015; ARES; VARELA, 2014; CADENA et al., 2014). Besides, allowing the assessor to more easily identify the main sensory characteristics responsible for the similarities and differences between samples, due to the direct comparison with the references presented. This advantage is especially greater in relation to other sensory analysis techniques, where comparison is made monadically and depends on the panelist memory, among other factors that occur at the moment of the evaluation, such as concentration during the execution of the task (ANTÚNEZ et al., 2015).

Some authors reported that PSP seems to be a quick and interesting methodology for sensory characterization of products (DE
SALDAMANDO et al., 2013; TEILLET, 2014; VARELA et al., 2014). De Saldamando et al. (2013) suggested that this method present a clear advantage over projective mapping and sorting tasks, particularly when working with samples with persistent flavours, or when a large number of samples should be evaluated over a long period of time or for quality control.

In addition to being able to differentiate beverages, it also allowed the identification of the main sensory characteristics of samples through consumer perception. Sample G1 was described mainly with the terms light, thin, mild aroma and flavor, weak and tasteless flavor. Samples S1 and S2 were mainly characterized by the attributes acid taste, strong and characteristic aroma. The samples T1, T2, T3 and G2 were associated to the attributes burnt aroma and flavor, dark, without oiliness and bad.

The sensory attributes used to characterize the samples were consistent with their type of roasting process (Table 1). The traditional samples $\mathrm{T} 1, \mathrm{~T} 2$ and $\mathrm{T} 3$, of medium roast, were related to 
burnt aroma, while the gourmet sample G1, of light roast, was associated to the terms light color, thin, mild aroma and flavor, weak and tasteless flavor. A good consistency was also observed in the association of attributes burnt, dark, without oiliness with the term bad for taste and aroma, when consumers described traditional beverages, in the same way that they associated the attributes light, thin and mild to the terms pleasant aroma and taste for the description of the samples superior S1 and gourmet G1. These results indicate that main sensory characteristics that consumers consider when defining coffee as pleasant or bad are related with roasting conditions. In this case, the study also indicates the inferior quality of Brazilian traditional coffee when compared with especialty coffees. Consumers, who increasingly have access to superior and gourmet coffees, were able to discriminate and provide sensory characteristics of coffee beverages making an inference of a quality classification according to their perception and language.

Preprocessing of words generated by consumers may have led to loss of information during text interpretation, which may have contributed to the reasonable explanation of variance $(50.43 \%)$ in the main dimensions of the sensory map. In the preprocessing of the words generated by the consumers of this study, there may have been a bias in the loss of information during the interpretation of the text. It is important to emphasize that the analysis of descriptive terms obtained through consumers in the description task is a time-consuming, laborious and difficult to perform and interpret (VARELA; ARES, 2012). Consumers write their comments without guidance, using their own writing style and sometimes with spelling and grammatical errors. Therefore, this initial verbalization needs to be preprocessed in order to obtain the final descriptions used in data analysis. Rostaing et al. (1998) mentioned the following steps necessary for the initial verbalization treatment: removal of errors, elimination of connectors and auxiliary terms, contextualization of sentences and terms that comprise them, lemmatization, regrouping of synonyms and management of ambiguous words. In most cases, this processing is done manually and, at some point, arbitrary decisions are made about synonymy, ambiguous terms and/or intensities. This decision-making is a crucial step in recovering reliable results without losing important information. As a way to minimize this risk, some authors (ARES et al., 2010; GALMARINI et al., 2013; NIEDOMYSL; MALMBERG, 2009) performed the classification and synonymy of words individually by more than one researcher. In this study, this treatment was manual, by a sensory analyst. There are recommendations for the use of some tools developed by these authors: Microsoft Excel macro, called "texttocolumn" (Microsoft Excel v. 2010), and some particular macros (available on request).

\section{CONCLUSION}

The PSP method was effective in the sensory characterization of coffee using consumer perception. The technique was adequate in both the differentiation aspect, including beverage classification according to the PQC of ABIC, and indicating the main sensory characteristics that direct beverage quality according to the consumer point of view, besides presenting advantages over the conventional descriptive profile regarding the time to perform the analysis. Despite being classified with a gourmet label, one of two gourmet sample were positioned at sensory configuration together traditional beverages, possiblly because they had similar sensory characteristics, and/or because sensory dimension generated is linked with the set of samples avaliated.

Main sensory characteristics that consumers consider when defining coffee as pleasant or bad are related with roasting conditions: attributes burnt, dark, without oiliness were assossiated with the term bad for taste and aroma, in the same way that they associated the attributes light, thin and mild to the terms pleasant aroma and taste. The results indicate that consumers were able to perceive the inferior quality of traditional Brazilian coffee, possibly due to the popularization of specialty coffees nationally marketed.

\section{REFERENCES}

ASSOCIAÇÃO BRASILEIRA DA INDÚSTRIA DO CAFÉ - ABIC. Marcas Certificadas Rio de Janeiro, 2014. Disponível em:_<http://abic.com.br/ certificacao/qualidade/marcas-certificadas/>. Acesso em: 14 out. 2014.

ALVES, G. E.; et al. Physiological and sensorial quality of Arabica coffee subjected to different temperatures and drying airflows. Acta Scientiarum. Agronomy, Maringá, v. 39, n. 2, p. 225-233, Apr/June. 2017. 
ANTÚNEZ, A. et al. Evaluation of data aggregation in Polarized Sensory Positioning. Journal of Sensory Studies, v. 30, n. 1, p. 46-55, Feb. 2015.

ARES, G. et al. Are consumer profiling techniques equivalent for some product categories? The case of orangeflavoured powdered drinks. International Journal of Food Science and Technology, Christchurch, v. 46, n. 8, p. 1600-1608, Aug. 2011.

ARES, G. et al. Comparison of two sensory profiling techniques based on consumer perception. Food Quality and Preference, Barking, v. 21, n. 4, p. 417426, Jun. 2010.

ARES, G. et al. Further investigations into the reproducibility of check-all-that-apply (CATA) questions for sensory product characterization elicited by consumers. Food Quality and Preference, Barking, v. 36, p. 111-121, Sept. 2014.

ARES, G. et al. Pole selection in polarized sensory positioning: insights from the cognitive aspects behind the task. Food Quality and Preference, Barking, v. 46, p. $48-57$, Dec. 2015.

ARES, G.; VARELA, P. Comparison of novel methodologies for sensory characterization. In: Novel techniques in sensory characterization and consumer profiling. Boca Raton: CRC Press, 2014. p. 365-389.

ARRUDA, A. C.; et al. Justificativas e motivações do consumo e não consumo de café. Ciência e Tecnologia de Alimentos, Campinas, v. 29, n. 3, p. 754-763, out/ dez. 2009.

ASSOCIAÇÃO BRASILEIRA DA INDÚSTRIA DO CAFÉ - ABIC (2004). Norma de Qualidade Recomendável ABIC/PQC, de 28 de Abril de 2004. Rio de Janeiro, 2004. Disponível em: <http://www. abic.com.br/publique/media/NMQ_LEGISLAcaO NORMAQUALIDADE.pdf>. Acesso em: 20 nov. 2015.

ASSOCIAÇÃO BRASILEIRA DA INDÚSTRIA DO CAFÉ - ABIC. Programa de Qualidade do Café PQC. Rio de Janeiro, 2017. Disponível em: <http:// www.abic.com.br/publique/cgi/cgilua.exe/sys/start. htm?sid=15>. Acesso em: 24 jul. 2017.

BRAZIL SPECIALTY COFFEE ASSOCIATION BSCA. Certificação. Minas Gerais, 2017. Disponível em: <http://brazilcoffeenation.com.br/certificacao $>$. Acesso em: 24 July. 2017.
BRUZZONE, F.; ARES, G.; GIMÉNEZ, A. Consumers' texture perception of milk desserts II - Comparison with trained assessors' data. Journal of Texture Studies, v. 43, n. 3, p. 214-226, Jun. 2012.

CADENA, R. S. et al. Comparison of rapid sensory characterization methodologies for the development of functional yogurts. Food Research International, v. 64, p. 446-455, Oct. 2014.

CENTRO DE DESENVOLVIMENTO TECNOLÓGICO DO CAFÉ - CETCAF. Café com qualidade (Colheita e Pós-colheita). Disponível em: <http://www.cetcaf.com.br/Apostila Cafe Com Qualidade - 2014>. Acesso em: 29 set. 2017.

DEHLHOLM, C.; BROCKHOFF, P. B.; BREDIE, W. L. P. Confidence ellipses: A variation based on parametric bootstrapping applicable on multiple factor analysis results for rapid graphical evaluation. Food Quality and Preference, Barking, v. 26, n. 2, p. 278280, Dec. 2012.

DOOLEY, L.; LEE, Y. S.; MEULlENET, J. F. The application of check-all-that-apply (CATA) consumer profiling to preference mapping of vanilla ice cream and its comparison to classical external preference mapping. Food Quality and Preference, Barking, v. 21, n. 4, p. 394-401, June. 2010.

FERIA-MORALES, A. M. (1990) Changes in cup quality using innovate field practices. In: International Coffee Organization, London, England.

FLEMING, E. E.; ZIEGLER, G. R.; HAYES, J. E. Check-all-that-apply (CATA), sorting, and polarized sensory positioning (PSP) with astringent stimuli. Food Quality and Preference, Barking, v. 45, p. 4149, Oct. 2015.

FRANCISCO, J. S.; SANTOS, A. C. F.; BENASSI, M. T. Efeito das informações e características da embalagem na expectativa e aceitação de café solúvel adicionado de café torrado micronizado. Brazilian Journal of Food Technology, Campinas, v. 17, n. 3, p. 243-251, July/Sept. 2014.

GALMARINI, M. V. et al. Understanding apple consumers' expectations in terms of likes and dislikes: Use of comment analysis in a cross-cultural study. Appetite, v. 62, n. 1, p. 27-36, Mar. 2013. 
GROSSO, G.; et al. Coffee, Caffeine, and Health Outcomes: An Umbrella Review. Annual Review of Nutrition, Califórnia, v. 37, p. 131-56, Aug. 2017.

ISQUIERDO, E. P. et al. Quality of natural coffee subjected to different rest periods during the drying process. Ciência e Agrotecnologia, Lavras, v. 36, n. 4, p. 439-445, July/Aug. 2012.

JAEGER, S. R. et al. Check-all-that-apply (CATA) questions for sensory product characterization by consumers: Investigations into the number of terms used in CATA questions. Food Quality and Preference, Barking, v. 42, p. 154-164, June. 2015.

JAEGER, S. R.; et al. Check-all-that-apply (CATA) responses elicited by consumers: within-assessor reproducibility and stability of sensory product characterizations. Food Quality and Preference, Barking, v. 30, n. 1, p. 56-67, Oct. 2013.

LAAKSONEN, O. et al. Sensory properties and consumer characteristics contributing to liking of berries. Food Quality and Preference, Barking, v. 53, p. 117-126, Oct. 2016.

LADO, J. et al. Application of a check-all-that-apply question for the evaluation of strawberry cultivars from a breeding program. Journal of the Science of Food and Agriculture, Chichester, v. 90, n. 13, p. 22682275, Oct. 2010.

LAWLESS, H. T.; HEYMANN, H. Sensory Evaluation of Food: Principles and Practices. 2nd ed. New York: Springer, 2010. 587 p.

LÓPEZ-GARCÍA, F. J. et al. Producción y calidad en variedades de café (Coffea arabica L.) en Veracruz, México. Revista Fitotecnia Mexicana, Cidade do México, v. 39, n. 3, p. 297-304, sept/feb. 2016.

MACFIE, H. J. et al. Designs to balance the effect of order of presentation and first-order carry-over effects in hall tests. Journal of Sensory Studies, v. 4, n. 2, p. 29-148, Sept. 1989.

MODESTA, R. C. D. et al. Desenvolvimento e validação do perfil sensorial para bebida de café brasileiro. Boletim de Pesquisa, n. 22, 37 p., 1999. Rio de Janeiro: Embrapa Agroindústria de Alimentos, 1999. 37p.

MONTEIRO, M. A. M. Caracterização da bebida de café (Coffea arabica L.): Análise descritiva quantitativa, análise tempo-intensidade e testes afetivos. 2002. 158 p. Tese (Doutorado em Ciência e Tecnologia de Alimentos) - Universidade Federal de Viçosa, Viçosa, 2002.

MONTEIRO, M. A. M.; MINIM, V. P. R.; SILVA, A. F. Bebida café (Coffea arabica L.): Atributos sensoriais. In: IV SIMPÓSIO DE PESQUISA DOS CAFÉS DO BRASIL, 2005, Londrina. Resumos Expandidos... Brasília: Embrapa Café. Anais do IV Simpósio de Pesquisa dos Cafés do Brasil. (2005). Disponível em: $<$ http://www.sapc.embrapa.br/arquivos/consorcio/ spcb_anais/simposio4/p76.pdf $>$. Acesso em: 23 jul. 2016.

NIEDOMYSL, T.; MALMBERG, B. Do open-ended survey questions on migration motives create coder variability problems? Population, Space and Place, v. 15, n. 1, p. 79-87, Jan/Feb. 2009.

OLIVEIRA, A. L. et al. Sensory evaluation of black instant coffee beverage with some volatile compounds present in aromatic oil from roasted coffee. Ciência e Tecnologia de Alimentos, Campinas, v. 29, n. 1, p. 7680, Jan/Mar. 2009.

OSSANI, P. C. et al. Qualidade de cafés especiais: uma avaliação sensorial feita com consumidores utilizando a técnica MFACT. Revista Ciência Agronômica, Fortaleza, v. 48, n. 1, p. 92-100, jan/mar. 2017.

PINO, F. A.; VEGRO, C. L. R.; ASSUMPÇÃO, R. Sensory quality of out-of-home coffees in Sao Paulo, Brazil. Brazilian Journal of Food Technology, Campinas, v. 20, Jan. 2017.

REINBACH, H. C. et al. Comparison of three sensory profiling methods based on consumer perception: CATA, CATA with intensity and Napping ${ }^{\circledR}$. Food Quality and Preference, Barking, v. 32, parte B, p. 160-166, Mar. 2014.

ROUSSEAU, B. Sensory discrimination testing and consumer relevance. Food Quality and Preference, Barking, v. 43, p. 122-125, July 2015.

ROSTAING, H. et al. Analyse de commentaires libres par la techniques des reseaux de segments. In Fourth International Conference on the Statistical Analysis of Textual Data, JADT'98, May, 1998, Nice, France.

SALDAMANDO, L. et al. Polarized sensory positioning: Do conclusions depend on the poles? Food Quality and Preference, Barking, v. 29, n. 1, p. 25-32, July 2013. 
SANTOS, E. S. M. Perfil sensorial e aceitabilidade do consumidor para blends de bebidas de café preparadas com grãos arábica (Coffea arabica) e conilon (Coffea canephora). 2010. 83 p. Dissertação (Mestrado em Ciência e Tecnologia de Alimentos) - Universidade Federal Rural do Rio de Janeiro, Seropédica, 2010.

SANTOS, E. S. M. et al. Efeito de grãos conilon no perfil sensorial e aceitação de bebidas de café. Semina: Ciências Agrárias, Londrina, v. 34, n. 5, p. 2297-2306, set/out. 2013.

SILVA, A. F. Perfil sensorial da bebida de café (Coffea arabica L.) orgânico. 2003. 96 p. Dissertação (Mestrado em Ciência e Tecnologia de Alimentos) Universidade Federal de Viçosa, Viçosa, 2003.

SILVA, S. A. et al. Characterization and delimitation of the terroir coffee in plantations in the municipal district of Araponga, Minas Gerais, Brazil. Revista Ciência Agronômica, Fortaleza, v. 45, n. 1, p. 18-26, Jan/ Mar. 2014.

SILVEIRA, A. S. et al. Sensory analysis of specialty coffee from different environmental conditions in the region of Matas de Minas, Minas Gerais, Brazil. Revista Ceres, Viçosa, v. 63, n. 4, p. 436-443, July/ Ago. 2016.

TEAM. R. C. R. A Language and Environment for Statistical Computing, R Foundation for Statistical Computing, Vienna, Austria, Apr. 2014.
TEILLET, E. Polarized sensory positioning methodologies. In VARELA, P.; ARES, G. (Eds.). Novel techniques in sensory characterization and consumer profiling. Boca Raton: CRC Press, 2014. chap. 10 , p. $255-270$.

TEILLET, E. et al. Sensory methodologies and the taste of water. Food Quality and Preference, Barking, v. 21, n. 8, p. 967-976, Dec. 2010.

VARELA, P.; ARES, G. Sensory profiling, the blurred line between sensory and consumer science. A review of novel methods for product characterization. Food Research International, v. 48, n. 2, p. 893-908, Oct. 2012.

VARELA, P. et al. (2014). The best of both worlds: Rapidity and enhanced discrimination with a trained panel. Exploration of global and partial PSP with a descriptive step. In: 6th European Conference on Sensory and Consumer Research, p. 7-10 September, 2014, Copenhaguen, Denmark.

VEINAND, B. et al. Highlight of important product characteristics for consumers: comparison of three sensory descriptive methods performed by consumers. Food Quality and Preference, Barking, v. 22, n. 5, p. 474-485, Jul. 2011. 